\title{
OS IDEAIS REPUBLICANOS ONTEM E HOJE: IMPACTOS DO NEOLIBERALISMO NOS DIREITOS SOCIAIS
}

\section{THE REPUBLICAN IDEAS YESTERDAY AND TODAY: IMPACTS OF NEOLIBERALISM IN SOCIAL RIGHTS}

\section{DANIEL RUBENS CENCI}

Pós-Doutor em Geopolítica Ambiental Latino-americana, pela USACH - Universidade de Santiago do Chile. Doutor em Meio Ambiente e Desenvolvimento pela Universidade Federal do Paraná (2009). Mestre em Direito pela UNISC Universidade de Santa Cruz do Sul (2002). Professor da UNIJUI - Universidade Regional do Noroeste do Estado do Rio Grande do Sul nos cursos de graduação em Direito, Mestrado e Doutorado em Direitos Humanos, Professor do Mestrado em Sistemas Ambientais e Sustentabilidade junto ao DEAG/UNIJUI. Coordenou 0 Núcleo de Pesquisa do Departamento de Ciências Jurídicas e Sociais compondo o Comitê de Pesquisa da UNIJUI. Tem experiência na área de Direito, com ênfase em Direito Ambiental e áreas propedêuticas, atuando principalmente nos seguintes temas: conflitos socioambientais, sociedade sustentável, legislação ambiental, gestão de políticas públicas e desenvolvimento regional. Coordenador do grupo de pesquisa Cidade, Saúde e Sustentabilidade. Pesquisador colaborador do Projeto COMPARTE/ UE - com universidades de Madrid, Barcelona, Girona e Universidade de Manágua. Professor do curso de Doutorado em Desenvolvimento Regional e Sustentabilidade, em Posadas na UGD - Universidad Gastón Dacharry. Professor colaborador da UNITINERANTE.

TATIANE BURMANN Mestre em Direito pela Universidade Regional do Noroeste do Estado do Rio Grande do Sul (2014). Atuou como Procuradora do Município de ljuí/RS (2010-2015) e professora hora-aula na Universidade de Cruz Alta e na Fundação Educacional Machado de Assis (2015). Atualmente, doutoranda em Direito na Faculdade de 
Direito da Universidade de Lisboa e investigadora no Centro de Investigação de Teoria e História do Direito da Universidade de Lisboa.

\section{VANDERLISE WENTZ BAÚ}

Mestre em Direitos Humanos pela Universidade Regional do Noroeste do Estado do Rio Grande do Sul - UNIJUí (2014). Professora de Direito Processual Civil e Teoria Geral do Processo na Universidade de Passo Fundo - UPF, no curso de Graduação em Direito, desde 1999 e na Pós-graduação \& quot; lato sensu\&quot; em Direito Processual Civil, desde 2014. Coordenadora do Curso de Direito do campus de Carazinho da Universidade de Passo Fundo. Coordenadora do projeto de extensão \&quot;Balcão do Consumidor\&quot; da Faculdade de Direito da Universidade de Passo Fundo, campus de Carazinho. Tem experiência na área de Direito, com ênfase em Direito Processual Civil.

\section{RESUMO}

Que valor tem uma República quando suas relações não são capazes de combater o que conduz ao interesse privado, ao arbítrio, à subserviência perante o poder e, nem mesmo, potencializar a elevação dos indivíduos à participação cívica? Sendo esse, infelizmente, o atual contexto sócio-político do Brasil, o presente trabalho busca, através de uma revisão bibliográfica, analisar as possíveis falhas dos ideais republicanos, desde a sua origem, na Antiguidade, proporcionando uma reflexão sobre as alterações necessárias para a concretização de um republicanismo ético e moral.

PALAVRAS-CHAVE: Ideais; República; Sociedade; Valores.

\section{ABSTRACT}

What value does a Republic have when its relations are unable to combat what leads to private interest, agency, subservience to power, and not even to elevate the elevation of individuals to civic participation? The present work, in this context, seeks, 
through a bibliographical review, to analyze the possible flaws of republican ideals, from its origin, in antiquity, providing a reflection on the changes necessary for the achievement of an ethical and moral republicanism.

KEYWORDS: Ideals; Republic; Society; Values.

\section{INTRODUÇÃO}

A atualidade deste artigo não resulta somente da crise do tempo contemporâneo. Desde a Antiguidade se conhece que o compromisso com a coisa pública requer desinteresse e virtude, ética amiúde contradita pela real história do Homem. Daí a constante tensão entre a idealidade e a prática, pano de fundo que possibilita avanços e recuos num percurso em que, entre o consenso e o paradoxo, o otimismo épico da aventura humana, não raro, desagua no seu oposto. O presente trabalho, nestes termos, pretende apresentar uma reflexão e discussão plurais sobre os valores republicanos e a concepção republicana do Estado e da Nação, interligando o passado destes ideais com os desafios do presente.

Para tanto, o primeiro ponto discorre sobre as distintas bases ideológicas da tradição republicana emergidas na Idade Antiga. Não cabe aqui tratar de critérios específicos, mas sim tentar demostrar os principais legados greco-romanos que poderiam vir a influenciar o discurso da filosofia política hodierna. Ressalta-se que com o declínio do Império Romano e a dualidade clássica romana virtú e fortuna houve um esvaziamento dos valores republicanos, o qual perdurou durante toda a Idade Média em favor dos da vontade divina.

Já o segundo item tem como objeto a retomada dos ideais republicanos no mundo moderno. À primeira vista, procura-se demonstrar que os ideais republicanos reavivados pela Renascença - em especial, o pensamento político sustentado na apologia maquiavélica da república - serviram de base ideológica à revolução da consciência cívica em curso. Num momento subsequente, atenta-se para a literatura desenvolvida séculos depois de Maquiavel, atrelada às Revoluções Americana e Francesa, que, ao remeter as múltiplas caracterizações de res publica para o ideal 
de governo livre e, em alguns casos, para o Estado livre, em defesa da tirania, do despotismo e da corrupção, colocou em causa a aplicação de alguns valores do republicanismo clássico à modernização da Monarquia.

O terceiro tópico, por fim, versa a respeito da concepção de república da idade contemporânea, e, consequentemente, sobre o deficit de ideias republicanos com que ela convive. Uma verdade é que o regime republicano pretendeu ser uma tentativa de modernização e de secularização; outro também fato é que seu projeto está muito aquém daquilo que originalmente pretendia-se. Pode-se até dizer que a atual míngua de ideais republicanos atormenta mais do que as suas décadas perdidas.

Perante essa falha de ideais republicanos, o desafio é conseguir extrair ensinamentos dos erros cometidos para efetuar as necessárias correções resultantes do presente do passado, do presente do presente e divisar um presente do futuro mais alentador. Pois, qual é o valor de uma República quando suas relações não são capazes de combater o que conduz ao interesse privado, ao arbítrio, ao servilismo perante o poder e, nem mesmo, potencializar a elevação dos indivíduos à participação cívica?

\section{AS BASES IDEOLÓGICAS DA PREMISSA REPUBLICANA}

O pensamento republicano ${ }^{1}$, e, por conseguinte, a emergência da própria ideia de política, desponta na Antiguidade clássica, inicialmente com as teorias dos filósofos gregos Platão (427-327 a.C) e Aristóteles (384-322 a.C.), sucedidas, não só temporalmente, pela dos pensadores romanos, o historiador Políbio (200-120 a.C) e o político e orador Cícero (103-43 a.C), o maior nome deste percurso. Tem-se, assim, duas grandes tendências republicanas com um substrato histórico comum,

\footnotetext{
1 Das ideias do termo república espalhadas na dicionarização, de acordo com Catroga, tem-se que, para os clássicos, ela articulava-se à concepção de pátria, numa espécie de patriotismo religioso. Todavia, ela também possuía um significado que a relacionava ao de res publica, enquanto sinônimo de luta pelo bem comum e pela liberdade, e, paulatinamente, de organização e constituição do poder político. Santo Agostinho sintetizou este modo atrelando-a ao sentido de res populi, como empresa do povo, de res patriae, enquanto empresa da pátria, e de res communis, uma empresa comum. $\mathrm{E}$ ainda, não será despropositado defender que o vocábulo politeia já se referia à comunidade, à coisa pública, ao bem comum (CATROGA, 2011).
} 
mas também traços distintos bastante significativos, que, em certa medida, acabaram por se completar.

Quanto aos pontos conjuntos do republicanismo greco-romano, destaca-se a implementação, por volta do ano 500 a.C., de "sistemas de governo que permitiam a participação popular de um significativo número de cidadãos (...) em bases tão sólidas que resistiram por séculos, com algumas mudanças ocasionais", vinculando a ideia de república à defesa da liberdade e ao papel central e responsável do exercício da cidadania (DAHL, 2001, p. 21). Também, a passagem pelo momento de decadência política e a possibilidade de reformulação de um ideal coletivo capaz de recuperar a unidade política - apesar da marcante segregação social. Segundo Fioravanti (2001), essa transição buscou a formação de um governo adequado, a partir de um simples sistema de organização e controle dos diversos componentes da sociedade historicamente construída, desvinculado da atual concepção das figuras de soberania, de poder, e muito menos de Estado - ou seja, inconfundível com a proposta política formulada na modernidade.

No que diz respeito às diferenças, tem-se, sequencialmente, as principais características do pensamento republicano grego e romano.

\subsection{DO LEGADO GREGO AO PENSAMENTO REPUBLICANO}

O legado grego ao pensamento republicano é, para além de históricoinstitucional, ainda filosófico. Parafraseando Gilissen (1979, p. 73 e ss), os gregos foram "os grandes pensadores políticos e filosóficos da Antiguidade. Foram os primeiros a elaborar uma ciência política; e na prática instauraram nas suas cidades regimes políticos que serviram de modelo ao Ocidente". Nesse contexto, o problema que a história da Grécia coloca é, sobretudo, em que medida a evolução do seu pensamento consistiu numa unidade ou representou uma lógica, ou ainda, em que grau este pensamento contribuiu para transformar a vida dos homens e a concepção de sociedade moderna.

É tempo de retomar a caracterização da cidade grega. O modelo da polis grega - mais precisamente, o modelo ateniense, uma comunidade que se autoconstituiu e se autogovernou, mediante o exercício direto do poder pelos seus 
membros, como expressão da própria ideia de liberdade, tornou-se paradigma às leituras republicanas clássicas. Sua soberania era competência exclusiva dos cidadãos, os quais legislavam, executavam e julgavam - a lei perdeu o caráter divino e passou a ser entendida como comando da vontade geral, patenteando-se, desta maneira, o primado da lei no mundo grego, base da sua filosofia e a diferença entre o sistema da polis e o das civilizações Pré-Clássicas. Há, assim, na polis, conforme Isabel Banond (1999, p. 372), "uma identificação do conjunto dos cidadãos do território com a noção de Estado: daí o termo cidade-estado. O Estado confundia-se com a comunidade que representava, mais do que com o território".

Ademais do modelo organizacional da polis, o legado ateniense ao republicanismo é igualmente filosófico. A origem do delineamento da noção de república residiu no pensamento aristotélico, que, criticando a proposta de Platão², afirmou ser o homem um animal político, cuja natureza era a polis, bem como anunciou a virtude humana, sobre a qual se edificou a organização política ateniense. ${ }^{3}$ Para tanto, Aristóteles, na sua obra Política, acabou por empregar o termo politeia em duas acepções diferentes: uma, no sentido da constituição de um povo, realizada na perspectiva do interesse ou bem comum; outra, no sentido de que é o governo realizado por muitos no interesse comum - a qual se dedica a atenção no presente. ${ }^{4}$

Ou seja, segundo a teoria aristotélica, a politeia é sempre o governo exercido em vista do bem comum; e, posteriormente, a república (consagrada pela tradução clássica do significado específico de politeia) é sempre o governo exercido por muitos em prol desse bem comum. Entretanto, vincular o "republicanismo" de Aristóteles à defesa da democracia ${ }^{5}$ seria equivocado. Isso porque o governo de

\footnotetext{
2 A "república" platônica não passou de um assustador sistema totalitário, seja porque reduziu o indivíduo a uma mera engrenagem - de importância irrelevante - na satisfação do ser coletivo, seja porque o critério da moralidade ficou atrelado ao interesse do estado (POPPER, 1974).

${ }^{3}$ A noção de república aristotélica propõe, segundo Châtelet et al, em sentido diametralmente oposto a platônica, "tornar a filosofia praticável no seio da Cidade tal como ela é", atribuindo-Ihe "credibilidade como instrumento teórico capaz de determinar [...] qual a melhor Constituição e quais as virtudes e capacidades exigidas dos cidadãos" (CHÂTELET et al, 1985, p. 20-21).

${ }^{4}$ Ver a obra de Aristóteles, 1998.

${ }^{5}$ Com relação à democracia face às outras formas de exercício de poder suscitadas por Aristóteles, ver o item 4.1 da obra de BANOND, 1999. Destaca-se que a noção de igualdade que fundamentava a concepção de democracia grega era bastante restrita, porquanto apenas eram considerados cidadãos os homens atenienses maiores de 20 anos, excluindo-se mulheres, crianças, escravos e, especialmente, estrangeiros, da capacidade de participar na administração da justiça e do governo.
} 
muitos no interesse comum demandaria a excelência desses vários, ao passo que, "é possível, um, ou poucos, distinguir-se pela excelência; mas dificilmente um maior número de cidadãos poderá atingir a perfeição em todos os tipos de virtude" (ARISTÓTELES, 1998, p. 213).

Nesse contexto, verifica-se ainda que "todos os homens, em virtude da especificidade de terem uma característica distintiva - o logos, eram as únicas criaturas a ter acesso à eudaimonia (felicidade) e à capacidade de fazer julgamentos sobre o Bem e o Mau, o certo e o errado" (PINTO, 2003). A virtude cívica, então, insere-se na natureza constitutiva da polis enquanto dimensão pública do ser humano orientada ao bem comum.

Com isto, o pensamento republicano grego, especialmente o formulado por Aristóteles, sintetiza-se em uma república destinada a todo e qualquer cidadão que tenha comprometimento com a polis. Eis suas principais noções que, como se verá adiante, conformam o ideário subjacente à interpretação da republica moderna, reabilitados na linguagem republicana no mundo contemporâneo.

\subsection{DO LEGADO ROMANO AO PENSAMENTO REPUBLICANO}

O legado romano ao pensamento republicano ultrapassa as Histórias de Políbio e o império das leis ${ }^{6}$. É a concepção ciceroniana da política, sobretudo a sua percepção moral - uma boa política como obra dos homens - que aponta as características determinantes da república romana.

Para Cícero, res publica é a res populi. Isso significa, transcrevendo parte do diálogo de Cipião (o africano) da sua obra Da República, que é a república a coisa do povo, considerando tal, não todos os homens de qualquer modo congregados, mas a reunião que tem seu fundamento no consentimento jurídico e na utilidade

Logo, segundo dados apresentados por Held, a prerrogativa de intervir efetivamente nos negócios da polis era de uma minoria, uma vez que $60 \%$ dos atenienses correspondiam a escravos e dos $40 \%$ restantes ainda teria de se deduzir as mulheres e as crianças (HELD, 2001, p. 40).

6 Ver a obra de Políbio, 1996. Comparando a sua constituição à da perspectiva republicana grega especialmente à aristotélica, que pregou o requisito da constituição mista em face dos cidadãos, chamando-os continuamente para o exercício das virtudes cívicas -, tinha-se agora um mecanismo produtivo de limitações adstrito ao comportamento dos governantes. A teoria de constituição mista nas páginas de Políbio já não é uma teoria da disciplina social, mas sim, uma teoria da disciplina do poder, para qual a única moralidade cuja falta é temida e é posta em questão é a dos governantes. 
comum. ${ }^{7}$ Trata-se de uma definição clássica, a qual permite algumas conclusões: uma, que a república, mais do que uma mera forma de estado, é aquilo que pertence ao povo em seu conjunto; dois, que a base da associação popular é o acordo na justiça (iuris consensus); e três, que o seu fim é o bem ou utilidade comum (utilitatis communio). Todavia, o sentido e o alcance da concepção republicana ciceroniana está para além.

A noção de república, em Roma, traz em seu bojo, portanto, a ideia de sacrifício, em nome do compromisso, do dever para com a coletividade. ${ }^{8}$ Enquanto na concepção aristotélica a participação dos assuntos da polis configurava uma dimensão constitutiva da natureza humana (zóon politikón), em Roma constrói-se a ideia de existência de um bem comum, coletivo, superior aos interesses individuais, justificadores da abdicação aos interesses privados, em que a participação dos assuntos da polis está vinculado ao desiderato de utilidade comum, sob os ditames da justiça, de modo a salvaguardar os interesses de cada cidadão.

Conquanto possam ser sólidas as sociedades fundamentadas no consenso de costumes e na coletividade, o fundamento absoluto de Cícero para o respectivo vínculo social centra-se na ideia de justiça agregada à de generosidade. Isso porque, na sua concepção, com justiça, associada à boa-fé, isto é, fidelidade e verdade nos compromissos assumidos, é possível evitar que um indivíduo cause dano a outro, salvo exceções de injustiças, bem como assegurar o proveito dos bens aos seus respectivos usuários - os bens comuns à comunidade, e os particulares em proveito de cada um. Ou, ainda, sem uma suprema justiça, não se pode reger de modo algum a coisa pública. ${ }^{9}$

Portanto, como bem sintetizado por Catroga (2011, p. 42), a proposta política de Cícero chamou-se res publica, uma

[...] moderada mistura (CíCERO, 2008), ideal que exigia a concomitante participação dos interesses da plebe e da aristocracia no negócio equilibrado da "coisa pública». Daí a sua superioridade: tratava-se de um regime "ponderado", o mais compatível com o cumprimento da virtude cívica.

\footnotetext{
${ }^{7}$ A respeito, ver a obra Cícero, 2011.

${ }^{8}$ Sobre o assunto, consultar Cícero, 2008a; Cícero, 2008b.

${ }^{9}$ Nesse contexto, os dizeres da obra de Cícero, 2011.
} 
Ou seja, é lícito dizer que a res publica é a pertença de todos; que seu elemento de coesão é a justiça; que a virtude cívica opera na convergência de fatores que entretenham a justiça; que o bem comum é o seu píncaro, enquanto padrão normativo de regulação justa da economia dos bens individuais e dos bens coletivos; e que o fim último da justiça é a ideia de liberdade.

Eis, consoante a interpretação que ora se propõe, os principais pontos do legado romano ao republicanismo. Lembra-se que os ideais republicanos, com o declínio do Império Romano e a dualidade clássica romana virtu e fortuna, deixaram de proclamar durante toda a Idade Média em favor dos da vontade divina, retornando apenas na Idade Moderna, com o Renascimento, mediante o resgate de diversas concepções gregas e romanas, que, posteriormente, justificariam as formas de organização política do Estado moderno.

\section{OS IDEIAS REPUBLICANOS NO MUNDO MODERNO}

O Renascimento, no plano político, importou na eclosão da consciência cívica, reavivando os ideais republicanos que se encontravam substituídos pelo teocentrismo durante o período da Idade Média. O historiador italiano da época, Nicolau Maquiavel, foi quem apresentou as bases ideológicas do imaginário político da Renascença. Séculos depois despertou uma corrente de pensamento atrelada às Revoluções Americana e Francesa que remeteu as múltiplas caracterizações de res publica para o ideal de governo livre e, em alguns casos, para o Estado livre, em defesa da tirania, do servilismo, do despotismo e da corrupção. Esses modernos ideais republicanos são os pontos abordados na sequência.

\subsection{O "RENASCIMENTO" DOS IDEAIS REPUBLICANOS}

O humanismo renascentista buscou nas ideologias da Antiguidade as referências para a consolidação do republicanismo ${ }^{10}$. Segundo Bignotto (2001, p. 67-

$10 \mathrm{O}$ retorno à tradição republicana representou, em face da multiplicidade de desenhos teóricos e institucionais denominados "repúblicas" no curso da história, e, por conseguinte, da impossibilidade 
68), "os humanistas desejavam servir-se do passado, não apenas para se confortarem com as verdades enunciadas pelos grandes autores, mas, sobretudo, para criarem sua própria identidade enquanto sujeitos de sua época". Prossegue o autor, o "paradigma fundante do humanismo é, portanto, o de retorno ao passado, mas de uma volta que permite o aparecimento de uma identidade no presente e não o mero elogio do acontecido". E, para além da necessidade dessa influência do clássico para os novos parâmetros de pensamento, a própria herança grega e sobretudo romana queria se fazer renascer, o que "não espanta encontrar-se uma maior valorização da vita activa e a subida de tom nos ataques contra a tirania" (CATROGA, 2011, p. 57).

Nesse cenário de retomada, as teorias de Cícero comportaram-se como um guia perfeito de retórica, história e filosofia moral (studia humanitatis), que, desprendendo-se das estéreis querelas escolásticas, apresentou aos humanistas uma nova visão, altamente positiva, das atividades na cidade. Embora Cícero não enfrentasse diretamente a questão da oposição entre interesse privado e interesse público, o que, sim, permitiria aos humanistas abordar o dilema entre a escolha de uma vida ativa ou de uma vida contemplativa, suas ideologias passaram a ter um objetivo de orientação prática para a vida pública, em especial, acerca da condução dos negócios da cidade - do alcance da grandeza, seja de status, de poder ou de riqueza.

Quanto ao paradigma fundante, o grande nome do republicanismo do renascimento foi o historiador italiano Maquiavel. Isso porque sua obra, os "Discursos sobre a Primeira Década de Tito Lívio", assumiu ampla representatividade no corpo de ideias que conformam a república renascentista. Em síntese, como contributo maquiavélico para o republicanismo, extrai-se da referida obra que a fortuna assistiria às repúblicas de preferência aos principados, pois, segundo Maquiavel, um único cidadão, habituado a proceder de determinada maneira, dificilmente é capaz de alterá-la, ainda que as circunstâncias se modifiquem, o que acarreta sua derrota; ao passo que as repúblicas "podem acomodar-se à diversidade dos tempos, em razão da diversidade dos cidadãos que

de tratar o republicanismo como uma corrente única de pensamento, guiada por um único projeto político, pelo menos, o retorno a uma série de debates e à preocupação com a esfera pública, pensada como lugar da efetiva ação dos cidadãos (BIGNOTTO, 2004). 
nelas há" (MAQUIAVEL, 2007, p. 352) .

Acontece que essa apologia que Maquiavel faz da república, depositada na liberdade nas mãos do povo, ultrapassa a defesa da democracia nos moldes atenienses, vez que está filiada ao ideal romano de constituição mista, de descentralização do poder entre o povo, o senado e os magistrados, sob a égide da lei. Para além disso, transpõe a diferença estabelecida por Aristóteles entre a democracia e a aristocracia, sob o argumento de que ambas correspondem a governos coletivos e sujeitos, portanto, de uma forma ou outra, a algum tipo de limitação.

Ademais, embora Maquiavel desenvolva o republicanismo, sua interpretação das relações sociais rompe, conscientemente, com a ideologia de Cícero e de toda a tradição sustentada no bem comum e na concórdia social e, por conseguinte, contraria frontalmente a tradição humanista que até então se desenvolvia no renascimento. Enquanto os humanistas, especialmente a partir de Petrarca - 0 ativo responsável pela retomada do pensamento ciceroniano -, apostavam na potencialidade do homem para, através da educação, tornar-se virtuoso, Maquiavel os criticava em defesa da importância da força na ação política.

Para Maquiavel, a discórdia atua como fator dinâmico de maximização do domínio do poder, ao passo que o bom senso recíproco converge ao acesso da liberdade comum, evitando que qualquer dos segmentos sociais sirva-se do poder em seu exclusivo benefício. Ou seja, no entendimento maquiavélico, os conflitos sociais seriam benéficos se e na medida em que favorecessem o bem comum, e não apenas determinados interesses seccionais. Caso contrário, se fosse colocada a satisfação de interesses faccionais acima da preservação do bem comum, a afligir os fundamentos da liberdade de todos, haveria uma autodestruição da tendência humana e ter-se-ia a noção maquiavélica de corrupção dos cidadãos. Nesse cenário, e no intuito de prevenir a corrupção e assegurar a liberdade comum em termos de independência, Maquiavel, inspirado na grandeza e na liberdade da república romana, deposita grande confiança na força coercitiva das leis, que 
pressupõe não apenas a previsão formal, mas também a instituição de mecanismos que the garantam efetividade. ${ }^{11}$

Por fim, Maquiavel (2007) denota apreensão com os riscos da descomedida concentração de poder em atores privados. Conforme o autor, a constituição e a estabilidade de uma república devem estar assentadas no equilíbrio de riquezas, pois o monopólio do poder na mão de um ou alguns cidadãos provoca perigos à liberdade. Ou seja, Maquiavel identifica, com êxito, acentuadas disparidades do poder privado como fator de abalo da liberdade comum, e, então, defende que uma república bem-ordenada está atrelada a manutenção do patrimônio público rico e dos cidadãos pobres. Eis exibido o "renascimento", tanto no sentido de retomar, bem como no sentido da época Renascença, dos ideais republicanos.

\subsection{A INVENÇÃO MODERNA DOS ANTIGOS}

A cultura republicana sempre deu relevo ao papel da vida ativa do homem perante à história, o que com a modernidade acentuou-se ainda mais. Porém, mesmo quando a sua mediação consciente visava construir o novo, não se deixava de apelar a fundamentos que the eram anteriores. Aconteceu, assim, tanto na Revolução Americana como na Francesa, senão vejamos.

O primeiro processo moderno de republicanização da res pública, o Americano, nasceu realizado em nome do povo e a partir de um pacto social, decorrente de uma revolução predominantemente política. ${ }^{12}$ Nesse processo, a concepção republicana acusava como principal escopo a defesa da liberdade, sustentada na predominância do interesse individual e na busca pela felicidade pessoal - afrontando diretamente os ideais republicanos gregos e romanos fundados que primavam pela coletividade e pelo bem comum, cuja garantia necessitava de

\footnotetext{
11 Segundo Skinner, na concepção maquiavélica, as leis devem ser estruturadas de modo a sustentar o tenso equilíbrio entre as forças sociais opostas, promovendo a vigilância recíproca e evitando tanto o domínio dos grandes quanto a licenciosidade do povo (SKINNER, 1981).

12 As treze colônias norte-americanas, após a Revolução Americana de 1776, constituíram o primeiro governo republicano liberal e a primeira grande república da Idade Moderna, denominada República Federativa dos Estados Unidos da América. Bobbio adverte que as treze colônias, embora tenham se autodefinido como república, adotaram uma constituição à imagem e semelhança de uma monárquica, vez que com chefe de Estado eletivo - ao invés de tradicional hereditário -, minimizando as diferenças teoricamente atribuídas à república com relação à monarquia (BOBBIO, 2012, p. 107).
} 
freios e contrapesos face o Estado, sob pena de se viver uma nova espécie de tirania: a exercida pelas maiorias legitimadas pelo sufrágio. Para tanto, adotou a lógica da separação dos poderes, bem como reformulou o conceito clássico de interesse público como equivalente à soma dos interesses particulares, em favor da lógica do interesse privado e, consequentemente, do enfraquecimento da formação de uma sociedade política.

Tem-se, nesse cenário, a inauguração da ideia de interesse, peça estrutural do pensamento republicano até o contemporâneo e da política como um todo. A respeito, Tocqueville dispõe que, o homem do povo, nos Estados Unidos, compreendeu a influência que a prosperidade geral tem sobre a sua felicidade, e, então, acostumou-se a encarar aquela prosperidade como obra sua. Por isso, vê na fortuna pública a sua própria fortuna e trabalha para o bem do Estado, não só por dever ou por orgulho, mas ousaria dizer que quase por cupidez. ${ }^{13}$

Para além do interesse, a organização política advinda da Revolução Americana de 1776 regia-se, sobretudo, pela noção de utilidade - o que significa, nada mais, do que o interesse bem compreendido. Tocqueville (1998) não nega que tais características implicam numa concepção moralmente fraca de bem público, e, logo, no risco da apropriação desse pelo privado, mas, por outro lado, defende que, do ponto de vista prático, o interesse público bem compreendido viabiliza o andamento político-administrativo de uma República.

Essa primeira concepção republicana liberal, contudo, contrasta com à posteriormente desenvolvida por Rousseau. Começa que, diferentemente, em França, a Revolução de 1789, "em razão de uma tábua de direitos naturais do homem que não se confinava aos chamados direitos subcjetivos", teve que liquidar a ordem social, política e cultural do Antigo Regime (CATROGA, 2011, p. 116). ${ }^{14} \mathrm{Tal}$ tábua de direitos atrelada aos direitos de liberdades impuseram à sociedade a obrigação da razão pública de promover ações positivas mínimas que igualizem as oportunidades - condição primordial para a realização mais plena da felicidade comum. Destarte, como bem sintetizado nas palavras de Spitz (2011, p. 139-159),

\footnotetext{
${ }^{13}$ A respeito, concultar a obra de Tocqueville, Alexys de. A democracia na América. Trad. e notas de Neil Ribeiro da Silva. 4 ed. São Paulo: Itatiaia, 1998.

${ }_{14}$ Segundo o autor em questão, referida tábua de direitos pode ser observada no conteúdo da Declaração dos Direitos do Homem e do Cidadão (1789) e das Constituições seguintes, 1793 e 1795.
} 
não pode haver verdadeira liberdade, onde as condições - do ponto de vista da riqueza privada e poder - são profundamente desiguais.

O republicanismo francês, em meados do século XIX, simultaneamente a estas características, mesclou, ainda, postulados jusnaturalistas com certo relativismo decorrente do crescente recurso a argumentos do histórico e sociológico, o que, a contrário do esperado, resultou no aumento da conviç̧ão de que a política seria uma arte não submetia aos caprichos da fortuna, porque orientada pelas ciências. Acreditava-se, em síntese, que "saber é poder", ou, na adaptação de Comte, "saber para prever, o fim de prover" (CATROGA, 2011, p. 117).

Ademais, o fato da experiência francesa ter sido esse processo de transformação completo, já que implicou oposição à questão política, social, religiosa e educativa do Antigo Regime, exigiu, ao contrário do que sucedeu na americana, um novo poder político legitimado pela soberania nacional, capaz de atuar como força instituinte de uma nova ordem social e mental. Como bem coloca Catroga (2001, p. 119) "o Estado-nação devia deter o monopólio do direito e da violência tendo em vista a garantia dos chamados direitos subjectivos - e agir, de um modo supletivo, sobre a população como Estado pedagogo, Estado higienista e instância prestadora de socorros públicos".

Dessa forma, na experiência francesa, inverso à tradição republicana americana, havia separação entre interesse público e privado, não sendo concebível a ideia liberal de que o mercado seria capaz de assegurar aos indivíduos uma condição de igualdade suficiente. Segundo Spitz (2011), o mercado é incapaz de, por si só, assegurar a igualdade de oportunidades, fazendo-se necessário, para tanto, a intervenção da coletividade, sustentada no princípio de reciprocidade e da vantagem mútua.

Rousseau (2012, p. 34-35) não deixa dúvidas quanto a essa concepção de república. Como efeito do seu contrato social, o lugar da pessoa particular de cada contratante foi substituído por um "corpo moral e coletivo composto de tantos membros quantas forem as vozes da assembleia". Esse corpo moral, essa "pessoa comum assim formada pela união de todas as outras tinha outrora o nome de Cidade e tem agora o nome de República ou de corpo político, o qual é chamado por seus membros Estado, quando passivo, Soberano, quando ativo, Potência, quando 
comparado a seus semelhantes". Assim, para Rousseau, o corpo político monopoliza o interesse coletivo e, quando das exceções da participação do indivíduo na esfera pública, esse, no caso de divergência, necessariamente, terá que se curvar àquele. ${ }^{15}$

O fato é que, a concepção republicana adotada pelos franceses, embora, ao privilegiar a coletividade em detrimento do interesse particular, tenha retomado os elementos mais característicos da república clássica, quando da centralização do poder impediu a República de cumprir com a (re)atualização do princípio clássico da participação, resquício da lição da liberdade dos antigos perdido na representatividade privilegiada pela liberdade dos modernos - motivo de críticas de muitos conservadores e contra-revolucionários. Ademais, o centralismo, ao tornar opaca a relação entre representantes e representados, teria feito crescer a burocracia e o clientelismo, vícios que estariam a bloquear o desenvolvimento dos sentimentos patrióticos e da virtude política.

Das invenções modernas dos antigos, eis que, a estrutura estatal herdada da Revolução não só se manterá como, no terreno político, continuará a diferenciar a via francesa, "mais democrática", da seguida pelos republicanos americanos, "mais aristocrática". E que, no pluralismo das soluções republicanas, e à revelia da ditadura pela ortodoxia positiva, predominou o propósito de equilibrar as premissas do liberalismo político com a prestação estatal de alguns serviços sociais.

\section{A CONCEPÇÃO PROCEDIMENTAL DA REPÚBLICA CONTEMPORÂNEA}

Nas últimas décadas do século XX, ganhou curso uma importante reflexão sobre o republicanismo, tema que, devido a novas hegemonias ideológicas, se tinha eclipsado após a I Guerra Mundial. No entanto, o reenquadramento histórico na

15 Benjamin Constant critica a concepção republicana de Rousseau. Alega que a centralidade do indivíduo prevista no pacto social rousseauniano é contrária à lógica da política moderna, pois, ao invés de reforçar o sujeito individualmente considerado, prioriza, em detrimento dele, a comunidade na qual ele se insere (CONSTANT, 2016). 
fundamentação do que se pretende demostrar não deixa de ser sintomático, o que exigi a permanente renovação de diálogos entre os antigos e os modernos ${ }^{16}$.

Os modernos, retomando as tradições das primeiras Repúblicas, perceberam que a ideia de liberdade, na perspectiva republicana contemporânea, não poderia ser, em hipótese alguma, reduzida à noção de liberdade dos liberais, fundada na ausência de intervenção pública no âmbito privado. Neste horizonte, Philip Pettit (1999) associou a ideia de liberdade à de "não dominação". O mencionado filósofo político entende que a dominação enquanto exercício de certo poder, de fundamento arbitrário, de um agente determinado sobre outro - os quais podem ser indivíduos, corporações ou autores coletivos -, implica uma piora na qualidade de vida do sujeito.

Contudo, "a salvaguarda da liberal «liberdade negativa», para ser justa, teria de pressupor, pelo menos um mínimo de «liberdade positiva»” (CATROGA, 2011, p. 117). Assim, o republicanismo, a qualquer tempo, para além de corresponder à defesa da liberdade de todos os cidadãos frente a eventuais abusos do poder político ou dos próprios, deveria, ainda, vincular a liberdade à possibilidade de exercício das virtudes cívicas, ou seja, à participação na esfera pública.

Ocorre que na prática, "hoje os termos [república e democracia] tendem a coincidir", uma vez que "as democracias são republicanas de fato (mesmo quando têm uma 'rainha da Inglaterra' à sua testa)" e as "repúblicas dignas de seu nome são necessariamente democráticas" (RIBEIRO, 2000, p. 173). É verdade que tais elementos caminham lado a lado na política contemporânea, entretanto, tecnicamente, estão centrados em apoios distintos: a democracia "é o regime do desejo, a república tem no seu âmago uma disposição ao sacrifício, proclamando a supremacia do bem comum sobre qualquer desejo particular" (RIBEIRO, 2008, p. 18). Ou seja, enquanto a democracia está mais vinculada à questão da aspiração, a república relaciona-se mais diretamente com a noção de poder político.

Mas, todo desejo por bens econômicos não é, em última análise, também uma luta pelo poder? A respeito, Ribeiro $(2008$, p. 15-16, 21) defende que a diferenciação entre luta social e desejo é uma "façanha moderna" alcançada apenas

${ }^{16}$ Entre os autores modernos destacam-se J.A. Pocok, Quentin Skinner, Charles Taylor, Philip Pettit, Maurizio Viroli e Spitz, entre outros. 
através de uma "economização das relações humanas", onde "mesmo o que é qualitativo, como a vida ou a vida boa, tende a ser quantificado, em termos de meios e fins, em termos de investimentos e resultados". Trata-se de uma política sustentada em interesses, comumente, voltados para um viés econômico. Nesse contexto, a democracia não existe, essencialmente, para satisfação dos desejos, mas sim, porque o "povo detém o poder". Entretanto, nesses termos, "só há democracia quando ocorre uma responsabilização básica do povo por suas decisões" e, paralelamente a isso, "a questão republicana está, justamente, no autogoverno, na autonomia, na responsabilidade ampliada daquele que ao mesmo tempo decreta a lei e que deve obedecer a ela".

Com efeito, sob pena de a democracia não se concretizar, atendo-se a uma simples prática populista, necessário se faz o convívio entre as concepções democráticas e republicanas. Nesse sentido, prossegue o recém citado autor (2008, p. 22): "para dizê-lo numa só palavra, o problema da democracia, quando ela se efetiva - e ela só pode se efetivar sendo republicana - é que, ao mesmo tempo que ela nasce de um desejo que clama por realizar-se, ela também só pode conservarse e expandir-se contendo e educando os desejos".

A concepção contemporânea de república reside, portanto, numa situação antagônica: ao mesmo tempo que legitima a noção de bem comum superior ao particular e condena a apropriação do mesmo por interesses privados, também exige menos dos cidadãos, aceitando que os mesmos se movam por interesses particulares. Eis, no que diz respeito à virtu, tem-se, provavelmente, o mais causador dos problemas da república na atualidade: a continuada segregação da vida pública, a degeneração dos vínculos coletivos, que acarretam, em última análise, a uma ação política cada vez mais fundada em si mesmo.

A atual articulação entre o privado e o público, assim como entre a integração comunitária e política, transporta consigo o incontornável enigma da hierarquia dos afetos pátrios, isto é, dos sentimentos e reconhecimentos de pertença. Trata-se de uma leitura mais abstrata do patriotismo que, na prática, implica ambiguidades e tensões, já que a separação da ideia de cidadania de nação parece sugerir que, sem mais, os cidadãos estariam disponíveis para optarem, por 
pura decisão racional, valores comuns em detrimento de sentimentos de índole etnocultural, incluídos os nacionais, socializados há mais de dois séculos.

Tal situação é agravada pela globalização ${ }^{17}$, que, não se pode olvidar, tem trazido a ressureição e a metamorfose das nações. Com o fenômeno, local e global confundem-se e a concepção de tempo e de espaço é redefinida. ${ }^{18}$ As estruturas globais provocam e facilitam as movimentações - tanto aproximações, quanto afastamentos -, repercutindo no deslocamento ou dissolução das fronteiras e dos centros decisórios e pontos de referência, o que acaba por demandar a descentralização das ações políticas, económicas, sociais e culturais. A comunidade de cidadãos pensada segundo o regime moderno, de forma homogênea, aparece por toda a parte como heterogênea, desestabilizando o modelo vestfaliano de relações internacionais, assentado nos princípios da soberania, territorialidade, autonomia e efetividade.

Nesse novo panorama político social, o Estado-nação, categoricamente, não é mais $o$ ator principal, nem mesmo uma figura política acima da sociedade, mas somente uma instituição que a organiza, sofrendo, portanto, limitações internas e externas de todas as ordens em sua competência. Todavia, essa metamorfose de poder não representa a sua exclusão, nem quer dizer que ele deixou de ser, de uma hora para outra, uma das mais sólidas instituições políticas modernas, ou, ainda, que a sua presença deixou de ser fundamental ${ }^{19}$, apenas exige-Ihe adaptações e

\footnotetext{
17 A globalização afetou a capacidade monopolística do Estado de decidir sobre assuntos tidos como de ordem soberana, pois, ao impulsionar os fluxos transnacionais - que atravessam com facilidade as fronteiras e se articulam a partir de outros lugares e outros centros de poder -, retirou dos governos dos Estados a capacidade de controlar seus assuntos domésticos de forma exclusiva. Segundo Giddens, tal fenômeno impossibilitou a centralização e a concentração política, econômica e social na figura de um Estado-nação, vez que a intensificação das relações ocorre "em escala mundial, que liga localidades distantes de tal maneira que acontecimentos locais são modelados por eventos ocorrendo a muitas milhas de distância, [conectam o mundo numa complexa rede de relações de interdependência]" (GIDDENS, 1991, p. 69).

18 De acordo com Isabel Banond, "a modernidade via o tempo como algo dinâmico e o espaço como algo fixo. A globalização traz como uma das suas grandes inovações a dinamização não somente do tempo, mas também do espaço (BANOND, 2014, p. 541).

19 Para Milton Santos, o Estado continua robusto, uma vez que nem as empresas transnacionais, nem as instituições supranacionais dispõem de força para, sozinhas, instalarem-se dentro de cada território (SANTOS, 2002). Já Isabel Banond entende que, com a globalização, o Estado nacional perde a autonomia, uma vez que o poder de decisão resta concentrado e centralizado nas mãos de um pequeno grupo de grandes empresas transnacionais e instituições econômicas (BANOND, 2014).
} 
novas funções ${ }^{20}$, que, sim, marcam o esvaziamento dos seus ideias republicanos sua soberania e sua autonomia.

A fragilização é evidente, apesar de paradoxal. Se por um lado, o Estado já não pode mais querer regular a sociedade civil nacional por meio de seus instrumentos jurídicos tradicionais, dada a crescente redução de seu poder de intervenção, controle, direção e indução; por outro, ele é obrigado a compartilhar sua soberania com outras forças que transcendem o nível nacional. Também, ao mesmo tempo em que as fronteiras nacionais são significativamente fragilizadas, a ponto de se falar no fim dos territórios como reivindicação de monopólio e de exclusividade, são concomitantemente mais protegidas, incentivadoras de novos nacionalismos e reivindicações identitárias. ${ }^{21}$

Portanto, a contemporaneidade depara-se com o enfraquecimento progressivo da identificação coletiva e com a fragilização do Estado - seja pela sua sujeição a fatores externos de poder, que relativizam a ideia moderna de soberania, seja pela incapacidade de responder aos conflitos internos, seja pela crise de representação ${ }^{22}$ que afeta a estrutura formal de exercício do poder político. ${ }^{23} \mathrm{Tal}$

20 Como o auxílio à formação de blocos regionais e o fomento às organizações econômicas multilaterais.

${ }^{21}$ Nesse sentido, Boaventura de Sousa Santos, ao tratar princípio do Estado no cerne do sistema capitalista global, afirma que, enquanto do ponto de vista externo o Estado nacional parece ter perdido, em parte, a capacidade e, em parte, a vontade política para continuar a regular as esferas da produção (privatizações, desregulação da economia) e da reprodução social (retração das políticas sociais, crise do Estado-Providência), assim como a transnacionalização da economia e o capital político que ela transporta parecem o ter transformado numa unidade de análise relativamente obsoleta, não só nos países periféricos e semiperiféricos, como quase sempre sucedeu, mas também, crescentemente, nos países centrais; do ponto de vista interno, na intenção de compensar essa impotência externa, há um aumento do conservadorismo e do totalitarismo nacional. Esse, embora tenha intenção de devolver à sociedade civil competências por ela outrora desempenhadas para as quais, inclusive, não mais possui capacidade, acaba por repercutir numa congestão institucional da burocracia e na ineficiência do Estado (SANTOS, 1997, p. 88-89).

22 A noção de representação política - elemento que, ao lado da ideia de república, integra a democracia moderna - mostra-se, hoje, insuficiente para responder às demandas por democracia. De acordo com Dominique Leydet, vive-se um momento de dupla crise na esfera da representação, porquanto há um cenário de descrédito da representação tanto no significado que the atribui o liberalismo (qual seja, a condição de mandato, em que os representantes estão vinculados aos interesses particulares dos que the escolheram), quanto do significado que the atribui 0 republicanismo (qual seja, a ideia de representação eminente, segundo a qual os representantes políticos, eleitos, devem representar o interesse da nação como um todo - efetivando, assim, uma separação entre as esferas pública e privada) (LEYDET, 2004, p. 67-92).

$23 \mathrm{O}$ fato é que há uma forte redução da importância das forças sociais internas no que se refere à organização e às diretrizes do poder estatal, há uma crise do princípio da soberania nacional, princípio esse basilar do Estado Democrático de Direito. Ou, ainda, que o capital assumiu as rédeas das relações político-sociais. A respeito, Bedin dispõe que "o neoliberalismo representa, seja como 
cenário engendra uma concepção de república em que a "visão substancialista, nacional-popular, cede lugar a uma concepção procedimental, que se sustenta à base da autonomia privada e pública no interior de uma associação de sujeitos de direitos, livres e iguais" (VIANNA; CARVALHO, 2008, p. 134-135).

Mas, e quem garante que a dimensão formal do regime republicano seja suficiente para concretizar a ideia de república em nossas sociedades? Em que pese a defasagem histórica, a necessidade das formas institucionais terem um espírito correspondente que as anime, que Ihes dê vida e que permita a realização daquilo que elas apenas supõem, permanece atual; em outras palavras, faz-se imperiosa, na república procedimental contemporânea, uma cultura cívica capaz de ancorá-la. Até lá, o que temos é uma república incorporada como regime de governo dissociado de qualquer elemento social apto a lhe dar sustentação.

\section{CONCLUSÃO}

A república contemporânea enquanto regime de governo dissociado de qualquer elemento social apto a the dar sustentação denuncia o seu déficit de valores na (má) relação estabelecida, de modo geral, entre as pessoas e o direito, entre os cidadãos e o Estado, refletida, entre outros ${ }^{24}$, na "cultura" de descumprimento de regras, que tem obstado o progresso social e político do continente. $\mathrm{O}$ desrespeito às regras é um elemento sistêmico que decorre de uma deficiência tanto do sistema político quanto do jurídico, afetando os indivíduos, o Estado e igualmente particulares. ${ }^{25}$

Nesse contexto, e como um hodierno exemplo de déficit de ideal republicano, adverte-se para a corriqueira, mas não menos importante, limitação de

proposta teórica, seja como experiência concreta, uma grande ameaça aos direitos do homem, em especial aos direitos econômicos e sociais". Isso porque o esforço neoliberal persiste em preservar a antiga dicotomia público/privado como uma separação radical entre o político e o econômico. Ademais, o próprio sistema cria resistência em redimensionar as suas esferas - ambiente, economia/sociedade, cultura e sistema de governo/ democracia - a considerá-las como pressupostos de seu planejamento e função, e acaba por fomentar um pensamento de primazia de uma esfera sobre a outra, ao invés de uma rede de reciprocidade de ações (BEDIN, 1997, p. 80).

${ }^{24}$ A exemplo de déficit republicano citam-se a desigualdade social e o esfacelamento da noção de pertencimento.

${ }^{25}$ Nesse sentido, oportuna a leitura da obra de Eduardo Vera-Cruz Pinto, 2015. 
abordagem cultural das fragilidades políticas que desconsidera os vários graus de responsabilidade que os sujeitos conservam com relação à coisa pública. Mais precisamente, alerta-se para a emblemática corrupção, compreendida como o baixo nível de virtude cívica que a república contemporânea requer dos cidadãos que a ela pertencem, aqui inserida.

Não admira. A corrupção atual constitui-se a partir de "engates afetivos", fundamentados na ideia de interesse, evidentemente, privado, e apresenta-se como uma ameaça a república por esta refutar o uso privado da coisa pública, ou, ainda, um déficit republicano que deturpa a esfera pública, principalmente porque desvirtua a ideia de direito - mesmo no seu sentido mais puro de oposição à força.

Ora, se para os antigos a corrupção representava a deterioração da coisa pública por meio da usura dos costumes, agora sua dimensão consiste ao mau trato dos dinheiros públicos como sintoma maior à dos costumes, realizado tanto num processo de "captura do Estado", como também por grupos econômicos privados. Com efeito, a corrupção já não se trata apenas de um problema do Estado, mas principalmente de uma questão vinculada aos costumes políticos de um determinado grupo. O que agravou a incapacidade de o poder se armar e credibilizar foi, sobretudo, o fato de os republicanos não terem nunca logrado alargar a sua base social de apoio.

A verdade é que a noção de república admite, para além da dimensão institucional, um elemento social e simbólico, cuja desdém depaupera a apreciação dos valores republicanos e a faz, de certo modo, perder o sentido. Logo, para responder aos desafios e aos ideais contemporâneos, o republicanismo precisa ser retomado, não só como um regime de governo, mas, sobretudo, como instrumento de afirmação de uma "liberdade positiva", vinculada à capacidade de atuação na esfera pública, que possibilite enfrentar tanto a apatia das sociedades atuais, como a prevalência da ideia de interesse privado, reconstituindo a esfera pública, não só no que diz respeito ao Estado, mas, especialmente, no sentido social da ideia de república. Com efeito, os problemas como o de déficit de ideais republicanos, como, por exemplo, o descumprimento de regras e, por conseguinte a corrupção, passarão pela ressignificação da esfera pública, pela nítida distinção entre interesses públicos 
e privados, bem como pelo encontro de novos "engates afetivos", capazes de superá-los e, ainda, de sustentar a república.

Seja como for, isso tudo mostra que faz parte do ideário republicano, juntamente com alguns objetivos políticos, uns quantos desideratos morais - como há noutros ideários. Não há nenhum projeto ideológico que não esteja acompanhado de alguma dimensão moral, contudo, não parece que se possa falar em bom rigor, em ética republicana, no seu sentido verdadeiro, muito menos, na superioridade da mesma, até porque alguns dos valores de base que os republicanos reclamam para o seu ideário não são, de forma alguma, exclusivos da República.

\section{REFERÊNCIAS}

ARISTÓTELES. Política. Trad. António Campelo Amaral e Carlos Gomes. Lisboa: Veja, 1998.

BANOND, Isabel. A ideia de liberdade no mundo antigo: notas para uma reflexão. Revista da Faculdade de Direito da Universidade de Lisboa. Coimbra, Vol. XL, n. 1 e 2, p. 325-473, 1999.

. História das ideias políticas. Cascais: Princípia, 2014.

BEDIN, Gilmar Antonio. A sociedade internacional clássica: aspectos históricos e teóricos. ljuí: Ed. Unijuí, 2011.

. Os Direitos do Homem e o Neoliberalismo. 2.ed. ljuí: Unijuí, 1997.

BIGNOTTO, Newton. Origens do Republicanismo moderno. Belo Horizonte: Editora UFMG, 2001.

- Humanismo cívico hoje. In: BIGNOTTO, Newton (org.). Pensar a República. 2 reimp. Belo Horizonte: Ed. UFMG, 2008, p. 49-69.

Problemas atuais da teoria republicana. In: CARDOSO, Sérgio (org.). Retorno ao republicanismo. Belo Horizonte: Editora UFMG, 2004, p. 17-43.

BOBBIO, Norberto. Estado, Governo, Sociedade: para uma teoria geral da política. Trad. Marco Aurélio Nogueira. 18 reimp. Rio de Janeiro: Paz e Terra, 2012.

CATROGA, Fernando. Ensaio respublicano. Lisboa: Fundação Francisco Manuel dos Santos, 2011. 
CHÂTELET, François; DUHAMEL, Oliver; PISIER-KOUCHNER, Évelyne. História das ideias políticas. Trad. Carlos Nelson Coutinho. Jorge Zahar Editor: Rio de Janeiro, 1985.

CíCERO, Marco Túlio. Da República. 2011. Tradução de Antônio Cisneiros. Rio de Janeiro: Ediouro, s.d.

. Os deveres. Tomo I. Trad. Luiz Feracine. São Paulo: Escala, 2008a.

. Os deveres. Tomos II e III. Trad. Luiz Feracine. São Paulo: Escala, 2008b.

CONSTANT, Benjamin. Da liberdade dos antigos comparada à dos modernos. Disponível em: <http://caosmose.net/candido/unisinos/textos/benjamin.pdf>. Acesso em junho de 2016.

DAHL, Robert. Sobre a democracia. Brasília: Ed. da UNB, 2001.

FIORAVANTI, Maurizio. Constitución: de la Antigüedad a nuestros días. Tradución de Manuel Martínez Neira. Madrid: Editorial Trotta, 2001.

GIDDENS, Anthony. As conseqüências da modernidade. Trad. Raul Fiker. 2. ed. São Paulo: Editora UNESP, 1991.

GILISSEN, Jhon. Introdução histórica ao direito. Trad. A. M. Hespanha e M. Macaísta Malheiros. Lisboa: FCG, 1979.

HELD, David. Modelos de democracia. Madrid: Alianza Editorial, 2001.

LEYDET, Dominique. Crise da representação: o modelo republicano em questão. In: CARDOSO, Sérgio (org.). Retorno ao republicanismo. Belo Horizonte: Editora UFMG, 2004, p. 67-92.

MAQUIAVEL, Nicolau. Discursos sobre a Primeira Década de Tito Lívio. São Paulo: Ed. Martins Fontes, 2007.

MONTESQUIEU, Charles Louis de Secondat, baron de la. Do espírito das leis. Introd. E notas Gonzague Truc. Trad. Fernando Henrique Cardoso e Leôncio Martins Rodrigues. 2 ed. Col. Os Pensadores. São Paulo: Abril Cultura, 1979.

PETTIT, Philip. Republicanismo: uma teoria sobre la libertad y el gobierno. Trad. Toni Domènech. Barcelona: Paidós, 1999.

PINTO, Eduardo Vera-Cruz. História do direito comum da humanidade: ius commune Humanitatis ou Lex Mundi? V.I. Lisboa: AAFDL, 2003.

O futuro da justiça. Lisboa: Nova Vega, 2015. 
PLATÃO. A República. Trad. J. Guinsburg. São Paulo: Difusão Européia do Livro, 1965.

POLÍBIO. Historias. Vol. II. Livro VI. Madrid: Ed. Gredos S/A, 1996.

POPPER, Karl Raimund. A sociedade aberta e seus inimigos. Trad. Milton Amado. Vol. I. São Paulo: Ed. da Universidade de São Paulo, 1974.

RIBEIRO, Renato Janine. A República. São Paulo: Publifolha, 2001.

A sociedade contra o social: o alto custo da vida pública no Brasil. São Paulo: Companhia das Letras, 2000.

Democracia versus república: a questão do desejo nas lutas sociais. In: BIGNOTTO, Newton (org.). Pensar a República. 2 reimp. Belo Horizonte: Ed. UFMG, 2008, p. 13-25.

ROUSSEAU, Jean-Jaques. O contrato social. Trad. Paulo Neves. Porto Alegre: L\&PM, 2012.

SANTOS, Boaventura de Sousa. Pela mão de Alice: o social e o político na pósmodernidade. 4 ed. São Paulo: Cortez, 1997.

SANTOS, Milton. Por uma outra globalização. Do pensamento único à consciência universal. 9 ed. Rio de Janeiro: Record, 2002.

SKINNER, Quentin. Machiavelli: A Very Short Introduction. Oxford: Oxford University Press, 1981.

SPITZ, Jean-Fabien. La concepción francesa de la república. In: HUERTA, Marcos García de la; SCHNEIDER, Carlos Ruiz. República, liberalismo y democracia. Serie Republicana. Santiago: LOM Ediciones, 2011. p. 139-159.

TOCQUEVILLE, Alexys de. A democracia na América. Trad. e notas de Neil Ribeiro da Silva. 4 ed. São Paulo: Itatiaia, 1998.

VIANNA, Luiz Werneck; CARVALHO, Maria Alice Rezende. República e civilização brasileira. In: BIGNOTTO, Newton (org.). Pensar a República. 2 reimp. Belo Horizonte: Ed. UFMG, 2008, p. 131-154. 